\title{
TEETH ABNORMALITIES IN THE DOG
}

\author{
Z. PAVLICA ${ }^{1}$, V. ERJAVEC ${ }^{1}$, M. PETELIN ${ }^{2}$ \\ ${ }^{1}$ Clinic for Small Animal Medicine and Surgery, Veterinary Faculty, \\ University of Ljubljana, Ljubljana \\ ${ }^{2}$ Department of Oral Medicine and Periodontology, Medical Faculty, \\ University of Ljubljana, Ljubljana, Slovenia \\ Received June 26, 2000 \\ Accepted February 7, 2001
}

\begin{abstract}
Pavlica Z., V. Erjavec, M. Petelin: Teeth Abnormalities in the Dog. Acta Vet. Brno, 2001, 70: 65-72.

Teeth abnormalities can be genetically induced by disturbances in the differentiation of the dental lamina and the tooth buds, and are relatively common in dogs, especially in purebred and line-bred dogs in which the genetic fault has been perpetuated. They are most common in smallbreed dogs but occur in large breeds, too. The aim of our study was to investigate permanent tooth anomalies in dogs. In 627 dogs referred for dental treatment we observed the presence of hypodontia, impacted teeth, hyperdontia, supernumerary and hyponumerary roots, focal macrodontia, focal microdontia, gemination, concrescence, fusion, dilaceration and enamel pearls. Teeth anomalies were detected in $288(45.93 \%)$ dogs of different skull shape. The most common anomalies in the observed population were dilaceration of the root with $99(34.4 \%)$ third lower and upper incisors, fourth lower and upper premolars and first lower and upper molars involved and hypodontia with $93(32.3 \%)$ first and second lower and upper premolars, and third lower molars involved. The proportion of an uncommon anomaly, such as fusion, was statistically significant $(p<0.01)$ for second lower and upper premolars $34(11.8 \%)$ and lower and upper molars. $22(7.6 \%)$ dogs had hyperodontia. The most affected teeth were the second lower and upper incisors. In 18 $(6.3 \%)$ dogs we observed supernumerary roots. Hyponumerary roots, macro- and microdontia, gemination, concrescence and enamel pearls were found in less than $3 \%$ of presented dogs. Because of this close relationship between normocclusion and periodontal health, early identification of anomalies of the teeth can allow the veterinary dentist to follow the patient and plan the treatment at an appropriate time.

Dental disorders, development, dog, clinical importance
\end{abstract}

Developmental disorders can be genetically induced by abnormalities in the differentiation of the dental lamina and the tooth buds. They are also induced by abnormalities in the formation of the dental hard tissues, or caused by traumatic, chemical, and microbial irritations. They may result in anomalies in the number, size, shape or structure of the teeth (Schroeder 1991). Developmental dental disorders are wellrecognised clinical features in veterinary dental pathology especially in dogs. In more than 300 recognised breeds of dogs, deviations from the normal number or placement of the teeth are the most common dental anomalies (Evans 1993).

Anomalies in the number of teeth can be manifested as oligodontia where only a few teeth are present. Hypodontia, defined as one or more missing teeth, is very often presented in different breeds of dogs. Hypodontia in the permanent dentition is more frequent than in the primary dentition (Jorgens on 1980). When a primary tooth is congenitally missing, its permanent successor is likely to be missing too. Some systemic disorders as ectodermal dysplasia in the hairless breeds are connected to hypodontia in the permanent dentition. A tooth that remains unerupted beyond its normal time is considered to be impacted ( $S$ krabalak 1993). Some physical barrier in the eruption path can cause impaction of teeth.

Address for correspondence:

Assoc. prof. Zlatko Pavlica DVM, MS, PhD.

Clinic for Small Animal Medicine and Surgery

Gerbičeva 60,1115 Ljubljant Slovenia
Phone: +38614779277

E-mail: PavlicZ1@mail.vf.uni-lj.si

http://www.vfu.cz/acta-vet/actavet.htm 
Generally this is an acquired condition but it can be genetic. Impaction can be caused by trauma or simply because of the abnormal tooth position in the alveolus (Skrabalak 1993). In all breeds the supernumerary teeth or hyperdontia can occur in primary and/or permanent dentition, but it is more prevalent in the permanent dentition. Supernumerary teeth in the dentition most probably result from continued proliferation of the permanent or primary dental lamina to form a third tooth germ. It can also be caused by disturbances during tooth development (Dole and Spurgeon 1997). Accessory or supernumerary roots can be seen in dogs. Most commonly involved are the upper second (9\%) and third premolars $(10 \%)$. They are rarely found in upper and lower anterior teeth (Regizi and Sciubba 1993). Sometimes hyponumerary roots can be seen in second lower premolars, second and fourth upper premolars, where the most commonly missing root is palatal root and in second lower and upper molars (Wiggs and Lobprise 1997).

Variation in tooth size may be exhibited as macrodontia. It is the condition where the crown of the tooth is oversized but the root and pulp cavities are near normal (Wiggs and Lobprise 1997). This may be absolute, as seen in pituitary gigantism, or it may be relative owing to a disproportionately small maxilla and mandibula (Regizi and Sciubba 1993). The latter results in teeth crowding and possibly an abnormal eruption pattern suggest an insufficient arch space. Focal or localised macrodontia refers to an abnormally large tooth or group of teeth (V erstraete 1999). Microdontia refers to a tooth that is normal in general shape, but reduced in size. Teeth may actually be measured smaller than normal, as in pituitary dwarfism, or they may be relatively small in comparison with a large mandibula and maxilla. Focal or localised microdontia refers to a single tooth that is smaller than normal. The shape of these microdonts is often altered with the reduced size and of simple conical shape (Wiggs and Lobprise 1997).

Teeth vary greatly in shape. Morphological anomalies of developmental origin include: gemination, concrescence, fusion, dilaceration, dens invaginatus, dens evaginatus, taurodontism and enamel pearls (Pindborg 1970; Schroeder 1991; Regizi and Sciubba 1993). Gemination is defined as an incomplete development of two teeth from one enamel organ. This results in a structure with two completely or incompletely separated crowns with a single root and root canal. Occasionally we see complete cleavage or twinning. Gemination is seen in the deciduous as well as in the permanent dentition (Regizi and Sciubba 1993). Fusion is the joining of two tooth germs, resulting in a single large tooth. Fusion may involve the entire length of the tooth, or only the roots, depending on the stage of development of the tooth at the time of the union. The root canal can be shared or separated. The aetiology of gemination and fusion is unknown, but trauma has been suggested as a possible cause. Fusion is seen in the deciduous as well as in the permanent dentition (Ravn 1971). It may be difficult or even impossible to differentiate fusion of a normal tooth and an adjacent supernumerary tooth from gemination (Verstraete 1999). Concrescence is the fusion of adjacent already formed teeth by cementum. It may take place before or after eruption. It is a form of fusion, where the teeth are united by cementum only. It is thought to arise from trauma or crowding of teeth (Verstraete 1999). Dilaceration refers to a sharp bend, curve or angulation in the root or crown of a tooth. The cause is usually acute mechanical trauma during the development of the tooth. The curve or bend may occur anywhere along the length of the tooth. Hereditary factors are supposed to be involved only in a small number of dogs.

An enamel pearl or drop is a small, focal excessive mass of enamel on the surface of the tooth. It occurs most frequently in the bifurcation or trifurcation of the tooth. Occasionally the enamel pearl is supported by dentin, very rarely a pulp horn extends into it ( Wiggs and Lobprise 1997).

The aim of this study was to detect the frequency of developmental disorders of teeth in 
dogs and to find correlations between different shapes of the skull and anomalies of individual teeth. In addition, the clinical importance of different tooth developmental disorders will be discussed for each dental disorder.

\section{Materials and Methods}

Clinical procedures and groups of anomalies

A total of 627 dogs referred for dental treatment at the Veterinary Faculty - Clinic for Small Animal Medicine and Surgery in Ljubljana between January 1999 and March 2000 were included in the study. After induction of general anaesthesia radiograph images were taken. A standardised system was used for radiographic positioning, views, and technique. Standard dental radiograph unit, and intraoral dental film, sizes 0, 2 and 4 were used. Dental examination and periodontal charting was performed with a dental explorer and periodontal probe.

After completed dental treatment of each dog, the clinical and radiographic findings were compared. Unexpected clinical and especially radiographic findings were found in 288 dogs (45.93\%) of the 627 examined animals. Anomalies in the number of teeth and roots were divided as follows: hypodontia, impacted tooth, hyperdontia, supernumerary and hyponumerary roots. Anomalies in size and shape of the teeth were defined as follows: focal macrodontia, focal microdontia, gemination, concrescence, fusion, dilaceration and enamel pearls.

The sample of teeth was assigned to eleven groups as follows: 1. Central lower and upper incisors, 2. Second lower and upper incisors, 3. Third lower and upper incisors, 4. Lower and upper canines, 5. First lower and upper premolars, 6. Second lower and upper premolars, 7. Third lower and upper premolars, 8 . Fourth lower and upper premolars, 9. First lower and upper molars, 10. Second lower and upper molars, 11. Third lower molars.

Dogs were divided by the different shapes of the skull in five groups: 1 . Large mesaticephalic breeds, 2 . Small mesaticephalic breeds, 3. Large brachycephalic breeds, 4. Small brachycephalic breeds, 5. Large dolichocephalic breeds.

Statistical analysis

The cohort of dogs referred for dental treatment was evaluated for the presence or absence of different dental anomalies as described above. Statistical analysis was done of 288 dogs with dental anomalies. Statistical Package for Social Sciences (SPSS) program was used to evaluate the results. Results are presented as $\chi^{2}$ - test of homogenity. Exact calculation of tail probabilities was used to compare the value of dental anomalies by teeth and dogs of the different shape of the skull. A level of $p<0.05$ was chosen for statistical significance.

\section{Results}

Incidence of teeth anomalies by groups of teeth is presented in Table 1. Hypodontia was detected in 93 teeth situated in 3 first lower and upper first incisors, 1 third lower or upper incisor, 22 first lower and upper premolars, 22 second lower and upper premolars, 1 third lower or upper premolar, 5 fourth lower and upper premolars, 12 second lower and upper molars and 27 third lower molars. Significantly higher incidence was found in group 5 $\left(\chi^{2}=8.6\right), 6\left(\chi^{2}=4.7\right)$ and 11 of the teeth $\left(\chi^{2}=27\right)$. Six impacted teeth were detected, and this anomaly included 2 central lower and upper incisors, 3 first lower and upper premolars and 1 third lower molar. Significantly higher incidence was found in group $1\left(\chi^{2}=16.2\right)$ and $6\left(\chi^{2}=6.1\right)$.

Hyperdontia was detected in 22 teeth, namely, 2 in central lower and upper incisors, 5 in second lower and upper incisors, 2 in third upper incisors (Plate XI, Fig.1), 3 in first lower and upper premolars, 3 in third lower and upper premolars, 2 in second lower and upper molars, and 5 in third lower molars. Significantly higher incidence was found in group 2 of the teeth $\left(\chi^{2}=22.1\right)$.

Supernumerary root was detected in 18 teeth. This anomaly included 6 first lower and upper premolars, 8 third lower and upper premolars, 3 fourth lower and upper premolars and 1 second lower or upper molar. Significantly higher incidence was found in the fifth $\left(\chi^{2}=5.9\right)$ and in a seventh group of the teeth $\left(\chi^{2}=43.2\right)$. Hyponumerary root was detected in 8 teeth. Anomaly included 2 second lower and upper premolars, 2 fourth lower and upper premolars and 4 second lower and upper molars. Significantly higher incidence was found in the tenth group of the teeth $\left(\chi^{2}=4.8\right)$. Only one second and one-third upper incisor with microdontia were detected. Macrodontia was detected only in one second upper incisor. Dilacerations were detected in 99 teeth, 2 in first lower and upper incisors, 2 in second lower 
and upper incisors, 9 in third lower and upper incisors, 5 in second lower and upper premolars, 2 in third lower and upper premolars, 21 in fourth lower and upper premolars, 37 in first lower and upper molars, and 21 in second lower and upper molars. Statistical significance was found in third $\left(\chi^{2}=5.8\right)$, in eight $\left(\chi^{2}=8.3\right)$ and in ninth group of the teeth $\left(\chi^{2}=41.5\right)$.

Table 1

Incidence of the anomalies in the different groups of the teeth

\begin{tabular}{|l|c|c|c|c|c|c|c|c|c|c|c|}
\hline \multicolumn{1}{|c|}{ Anomalies } & \multicolumn{10}{|c|}{ Groups of teeth } \\
\hline & 1 & 2 & 3 & 4 & 5 & 6 & 7 & 8 & 9 & 10 & 11 \\
\hline Hypodontia & $3.2 \%$ & $0 \%$ & $3.1 \%$ & $0 \%$ & $23.7 \% *$ & $23.7 \% *$ & $2.1 \%$ & $5.3 \%$ & $0 \%$ & $12.8 \%$ & $29.8 \%$ \\
\hline Impacted teeth & $33.3 \%$ & $0 \%$ & $0 \%$ & $0 \%$ & $50 \% *$ & $16.7 \% *$ & $0 \%$ & $0 \%$ & $0 \%$ & $0 \%$ & $0 \%$ \\
\hline Hyperdontia & $9.1 \%$ & $22.7 \% *$ & $4.5 \%$ & $0 \%$ & $18.21 \%$ & $0 \%$ & $13.6 \%$ & $0 \%$ & $0 \%$ & $9.1 \%$ & $22.7 \%$ \\
\hline Supernumerary root & $0 \%$ & $0 \%$ & $0 \%$ & $0 \%$ & $33.3 \% *$ & $0 \%$ & $44.4 \% *$ & $16.7 \%$ & $0 \%$ & $5.6 \%$ & $0 \%$ \\
\hline Hyponumerary root & $0 \%$ & $0 \%$ & $0 \%$ & $0 \%$ & $0 \%$ & $25 \%$ & $0 \%$ & $25 \%$ & $0 \%$ & $50 \% *$ & $0 \%$ \\
\hline Dilaceration & $2.0 \%$ & $2.0 \%$ & $9.1 \% *$ & $0 \%$ & $0 \% *$ & $5.1 \% *$ & $2.0 \%$ & $21.2 \% *$ & $37.4 \% *$ & $21.2 \%$ & $0 \%$ \\
\hline Fusion & $0 \%$ & $0 \%$ & $0 \%$ & $0 \%$ & $0 \%$ & $44.1 \% *$ & $11.8 \%$ & $2.9 \%$ & $5.9 \%$ & $35.3 \% *$ & $0 \%$ \\
\hline
\end{tabular}

1 group of first lower and upper incisors 2 group of second lower and upper incisors

3 group of third lower and upper incisors

4 group of lower and upper canines

5 group of first lower and upper premolars

6 group of second lower and upper premolars

7 group of third lower and upper premolars

8 group of fourth lower and upper premolars

9 group of first lower and upper molars

10 group of second lower and upper molars

11 group of third lower molars

* significant at $p<0.05$

Only one second upper incisor with gemination was detected (Plate XI, Fig. 2). Concrescence was detected in 3 lower and upper canines (Plate XII, Fig. 3). Fusion was detected in 34 teeth, 15 in second lower and upper premolars, 4 in third lower and upper premolars, 1 in fourth lower or upper premolar, 2 on first lower and upper molars, and 12 in second lower and upper molars. Statistical significance was determined in sixth $\left(\chi^{2}=19.2\right)$, and tenth $\left(\chi^{2}=5.7\right)$ group of the teeth. Enamel pearl was detected in one first lower molar (Plate XII, Fig. 4).

Table 2

Percentage of observed anomalies according to different skull shape in dogs

\begin{tabular}{|l|c|c|c|c|c|}
\hline \multicolumn{1}{|c|}{ Anomalies } & \multicolumn{5}{|c|}{ Groups of different shape of the skull in the dog } \\
\hline & 1 & 2 & 3 & 4 & 5 \\
\hline Hypodontia & $32.6 \%$ & $31.7 \%$ & $0 \%$ & $0 \%$ & $70 \% *$ \\
\hline Impacted teeth & $4.3 \%$ & $1.4 \%$ & $0 \%$ & $0 \%$ & $10 \%$ \\
\hline Hyperdontia & $17.4 \% *$ & $3.2 \% *$ & $62.5 \% *$ & $0 \%$ & $20 \%$ \\
\hline Supernumerary root & $15.2 \%$ & $4.6 \%$ & $12.5 \%$ & $0 \%$ & $0 \%$ \\
\hline Hyponumerary root & $0 \%$ & $3.2 \%$ & $0 \%$ & $16.7 \%$ & $0 \%$ \\
\hline Dilaceration & $21.7 \%$ & $40.4 \%$ & $0 \%$ & $16.7 \%$ & $0 \%$ \\
\hline Fusion & $2.2 \%$ & $14.2 \%$ & $0 \%$ & $33.3 \%$ & $0 \%$ \\
\hline
\end{tabular}

1 large mesaticephalic breeds

2 small mesaticephalic breeds

4 small brachycephalic breeds

5 large dolichocephalic breeds

3 large brachycephalic breeds

* significant at $p<0.05$

Table 2 represents anomalies observed in five different groups of dogs. 93 (32.3\%) dogs had a hypodontia. Two way $\chi^{2}$ analysis (anomaly v.s. group of shape of the skull of the dog) indicates a significant difference $\left(\chi^{2}=4.5\right)$ in large dolichocephalic breeds. Impacted teeth appeared in 6 dogs. Hyperodontia was presented in 22 dogs. Statistically significant values were observed in large mesaticephalic breeds $\left(\chi^{2}=5.8\right)$ and in large brachycephalic breeds 
$\left(\chi^{2}=32.2\right) .18$ dogs had a supernumerary root, but the $\chi^{2}$ analysis was not significant for any of group of dogs. 8 dogs had a hyponumerary root, but the $\chi^{2}$ analysis was not significant for any of group.

Microdontia was observed only in 2 dogs. One case of macrodontia and one of gemination was observed in a Boxer, which presents the large brachycephalic breed.

Ninety nine dogs had a dilaceration of the root, but the $\chi^{2}$ analysis was not significant for any of group of dogs. Concrescence was presented in 3 dogs of large mesaticephalic breeds. Thirty-four dogs had the fusion of the roots, but the $\chi^{2}$ analysis was not significant. One German Shepherd as a large mesaticephalic breed had enamel pearls.

\section{Discussion}

The dog probably suffers from more hereditary dental abnormalities than any other animal, because of the difference in size and shape of breeds as well as from intensive and sometimes indiscriminate inbreeding (Kertesz 1993). Just like a foetus in utero, the forming tooth is very susceptible to various influences during periods of rapid growth and change (Wiggs and Lobprise 1997). Developmental dental disorders can be genetically induced by abnormalities in the differentiation of the dental lamina and the tooth buds. They may result in anomalies in the number, size and shape of the teeth (Schroeder 1991).

Our data clearly established the frequencies of the developmental disorders of teeth in 288 of the 627 dogs referred for a routine dental treatment. According to Thongudomporn and Freer (1998), hereditary factors are often involved in hypodontia, but the teeth can also be missing as a result of disturbances during initial development. Differentiation between possible hereditary and proven traumatic causes is important for breeding dogs. The prevalence of hypodontia (32.3\%) was found in 288 out of 627 examined dogs. This was significantly higher for large dolichocephalic breeds, and considerably higher than the prevalence reported by some other studies (Harvey and Emily 1993; Wiggs and Lobprise 1997; Dole and Spurge on 1998). The third lower molars were the teeth most frequently missing followed by the first lower and upper premolars, and the second lower and upper premolars. Generally an impacted tooth is an acquired condition. This is sometimes due to a mechanical interference and was seen in a high number in a group of Terriers (Harvey and Emily 1993; Pavlica and Cestnik 1996). It most frequently affects the first mandibular and maxillary premolars (Regizi and Sciubba 1993). Other premolars and canines are involved less commonly. It is rare to see impaction of incisors and molars.

In our study only $2.1 \%$ of dogs had an impacted tooth, and were found in a group of the large mesaticephalic breeds (4.3\%), small mesaticephalic breeds (1.4\%) and large dolichocephalic breeds (10\%). Impaction of the tooth can lead to dentigerous cyst formation, with a radiolucent cyst originating from the remnant enamel organ at the neck of the tooth (Tholen and Hoft 1990). These teeth should be removed or at least monitored on a regular basis.

The exact aetiology of supernumerary teeth remains widely unclear (Stellzig et al. 1997). Some breeds are overrepresented e.g. Boxer, Bulldog, Rottweiller. Supernumerary incisors and premolars can, but not necessarily, have a normal shape and size. According to Dole and Spurge on (1998), the extra teeth appeared as the result of a mutation that caused tooth duplication, a genetic change that unintentionally has been favoured as a result of inbreeding. Approximately $90 \%$ of all supernumerary teeth are incisors and premolars or sometimes molars, which are most frequently found in the maxilla, where they appear as mesiodens and distomolars or paramolars (Pindborg 1970; Schroeder 1991; Dole and Spurge on 1997). A prevalence of hyperdontia (7.6\%) was found in the total of 288 out of 
627 examined dogs. This was statistically significant in the group of large mesaticephalic and in the group of large brachycephalic breeds (Table 2). It was considerably higher than the prevalence reported in some other studies (Dole and Spurgeon 1998). Supernumerary teeth were observed directly caudal to the canine tooth, in the natural diastema, caudally to the third upper incisors as a peg lateral (Fig. 1), or at the distal end of the arcade.

In all instances teeth were presented where there was room for full eruption without adverse effects. It is not uncommon in the Boxer to find supernumerary maxillary incisors without crowding due to their wide brachycephalic bite (Skrabalak 1993). All these findings support the dichotomy theory of the split in the tooth bud inducing the development of supernumerary teeth. We favour this theory to that of local hyperactivity of the dental lamina. Supernumerary teeth may cause disturbances in eruption, crowding and deviation of teeth. In that case extraction needs to be considered. When these teeth do not cause clinical problems, they should not be extracted. The owner needs to be warned of the possible heritability of the disorder.

In some teeth or in some breeds supernumerary or accessory roots are so common, that they can be seen as an anatomical variation. Most commonly involved are the upper second (9\%) and third premolar (10\%) (Wiggs and Lobprise 1997). They are rarely found in upper and lower anterior teeth ( $\mathrm{Ravn} \mathrm{1971).} \mathrm{The} \mathrm{findings} \mathrm{reported} \mathrm{here} \mathrm{illustrate} \mathrm{that} \mathrm{the}$ third lower and upper premolars were the most frequently teeth with supernumerary roots (Table 1), followed by the first lower and upper premolars, fourth lower and upper premolars, and the second lower and upper molars. These results are in agreement with data from Wiggs and Lobprise (1997). Radiographic recognition of supernumerary roots is very important when endodontic treatment or extraction of the involved tooth is considered. In comparison with data reported in some other studies (Wiggs and Lobprise 1997) hyponumerary roots appeared significantly higher only in the group of the second lower and upper molars.

It is very difficult, due to differences in head and teeth shape between breeds, to objectively measure size as being too large or too small for a particular animal. Macrodontia is relatively uncommon condition, which is usually seen on central maxillary incisors. The condition is considered hereditary in humans also. In dog it is seen in Boxer (Verstraete 1999). In the observed population of the 288 out of 627 examined dogs only one Boxer had macrodontia in place of the second upper incisor. This finding is in agreement with the reports, which had been previously described by Verstraete (1999) and DeForge (1992). Mainly cosmetic, although a macrodont tooth might need to be extracted because of interference with comfortable occlusion.

Teeth presented in dogs with ectodermal dysplasia are often very small and of simple conical shape. Microdontia is most commonly seen palatal to the third maxillary incisor indicated as peg lateral (Wiggs and Lobprise 1997). An autosomal dominant inheritance pattern has been associated with this condition. Pegs lateral are of no significance, other than cosmetic appearance. We observed only one dog (a terrier) with two pegs lateral, that were palatal to the right and left third maxillary incisors. Other than aesthetic and some loss of function, it requires no treatment.

The aetiology of gemination remains widely unclear but trauma has been suggested as a possible cause in the time when the developing bud attempted to split but failed to do so completely (Rossman et al. 1985). The actual number of teeth is not altered in this condition.

However, the structure will be generally larger than normal, which may result in tooth crowding. The condition is common in the maxillary incisors of the Boxer without crowding (Wiggs and Lobprise 1997). In our study only one second upper incisor in one Boxer with gemination was detected (Fig. 2). 
The aetiology of a fusion is unknown, but trauma has been suggested as a possible cause. The fusion process is the result of two separate tooth buds joined at the crown by enamel and possibly dentin. There will be a reduced number of teeth, and the fused tooth will be smaller than the two separate teeth would have been, unless there is a communication of the junction groove of the two teeth that extends to or below the gingival margin. This disorder can trap food and contribute to periodontal disease (Wiggs and Lobprise 1997). A familial tendency appears to be responsible in dogs with fused incisors due to abnormal interdental laminar growth (Harvey and Emily 1993). A prevalence of fused teeth was found in $11.8 \%$ of the 288 out of 627 examined dogs. The $\chi^{2}$ analysis was significant in the group of second lower and upper premolars and in the group of second lower and upper molars (Table 1).

Concrescence is an uncommon tooth anomaly, with only a few cases described in the veterinary literature (Verstraete 1999). It is thought to arise from trauma or crowding of teeth and may take place before or after eruption. This relatively uncommon condition is usually seen in lower and upper canines and lower and upper first premolars, which was detected in our study in the group of large mesaticephalic breeds only (4.3\%) (Fig. 3).

According to Wiggs and Lobprise (1997) hereditary factors of dilaceration are supposed to be involved in a small number of cases. The cause is usually injury, infection or inflammation during the development of the tooth.

A prevalence of dilaceration with $34.4 \%$ was found for the total of 288 dogs. The first lower and upper molars were the teeth with the most frequently dilacerated roots followed by the fourth lower and upper premolars and second lower and upper molars.

Aesthetics, plaque-retentive surface, problems in extracting, or when performing an endodontic procedure must be considered as a clinical evidence in case of a dilacerated root. Severely dilacerated teeth might be unable to erupt.

Appearance of enamel pearls has been described also in dogs (Ros s man et al. 1985). In our study the enamel pearl was detected on the furcation of the fourth upper premolar in one German Shepherd and on the furcation of the first lower molar in one Maltese dog (Fig. 4). The fourth upper premolar and the first lower molar were the most commonly affected teeth. The periodontal ligament does not attach well to the tooth at the sites of enamel pearls, resulting in a long junctional epithelium within the sulcus, fenestrations and inflammation of the periodontium. An early detection should be important in prevention of periodontal disease.

Because of this close relationship between normocclusion and periodontal health we can conclude, that early identification of anomalies of the teeth can allow the veterinary dentist to investigate further and plan the treatment at the appropriate time.

\section{Abnormality zubů u psů}

Abnormality zubů mohou být geneticky podmíněny poruchami při diferenciaci zubní lišty a zubních pupenů. Jsou relativně běžným nálezem u psů, zejména čistokrevných a u psů z př́ibuzenské plemenitby, kde je genetická vada fixována. Abnormality byly častější u malých plemen psů, než u velkých plemen.

Cílem studie bylo zjistit trvalé anomálie zubů u psů. U 627 přijatých, dentálně ošetřených psů jsme diagnostikovali hypodoncii, vklíněný zub, hyperdoncii, nadbytečný nebo nedostatečný počet kořenů, ložiskovou makrodoncii a mikrodoncii, zdvojení, srůst, fúzi, dilaceraci a poruchy perlování skloviny. Zubní anomálie s atypickým tvarem lebky psa byly zjištěny u 288 (45,93\%) pacientů.

K nejčastějším anomáliím u sledované populace patřila dilacerace kořene 99 (34,4\%) třetích spodních a horních řezáků, čtvrtých spodních a horních premolárů a prvních spodních a horních molárů, hypodoncie u 93 (32,3\%) prvního a druhého spodního a horního premoláru a třetích spodních molárů. Rozsah anomálií, běžně se nevyskytujících, např. fúze, 
byla statisticky významná u druhého spodního a horního premoláru 34 ( 11,8\%) a u spodních a horních molárů. U 22 psů (7,6\%) jsme zjistili nadměrný počet zubů. Druhý spodní a horní řezák byl postižen nejvíce. Nadměrný počet kořenů mělo 18 psů $(6,3 \%)$. Nedostatečný počet kořenů, makrodoncie a mikrodoncie, geminace, srůst a poruchy skloviny byly popsány u méně než $3 \%$ psů vyšetřené populace. Vzhledem k úzkému vztahu mezi normookluzí a periodontálními vadami, umožňuje včasná identifikace anomálií další vyšetř̌ení a léčbu v optimální době.

\section{References}

DE FORGE, D. 1992: Dens in dente in a six year old Doberman Pinscher. J. Vet. Dent. 9: 3-5

DOLE, R.S., SPURGEON, T. L. 1998: Frequency of the supernumerary teeth in a dolichocephalic canine breed, the Greyhound. Am. J. Vet. Res. 59: 16-17

EVANS, H. E.1993: The digestive apparatus and abdomen. In: Evans H.E. Miller's anatomy of the dog. WB Saunders, Philadelphia, pp. 385-462

HARVEY, C. E., EMILY, P. P. 1993: Occlusion, Occlusive Abnormalities, and Orthodontic Treatment. In: Harvey, C. E., Emily P. P. Small Animal Dentistry. Mosby, St. Louis, pp. 266-296

JORGENSON, R. J. 1980: Clinician's view of hypodontia. J. Am. Dent. Ass. 101: 283-286

KERTESZ, P. 1993: Dental Development and Abnormalities. In: Kertesz, P. A Colour Atlas of Veterinary Dentistry and Oral Surgery. Wolfe, London, pp. 51-72

PAVLICA, Z., CESTNIK, V. 1996: Management of lingually displaced mandibular canine teeth in five bull terrier dogs. J. Vet. Dent. 12: 127- 129

PINDBORG, J. J. 1970: Pathology of the Dental Hard Tissues. Munksgaard, Kopenhagen, pp. 47-356

RAVN, J. J. 1971: Aplasia, supernumerary teeth and fused teeth in primary dentition. An epidemiologic study. Scand. J. Dent. Res. 79: 1-6

REGIZI, J. A., SCIUBBA, J. 1993: Abnormalities of Teeth. In: Regizi, J. A., Sciubba J.Oral Pathology. Saunders, Philadelphia, pp. 494-520

ROSSMAN, L. E., GARBER, D. A., HARVEY, C. E. 1985: Disorders of teeth. In: Harvey, C.E. Veterinary Dentistry. Saunders, Philadelphia, pp. 79-91

SCHROEDER, H.E. 1991: Developmentand Structure of the Tissues of the Tooth, Clinical Consideration. In: Schroeder, H. E. Oral Structural Biology. Thieme, Stuttgart, pp. 171-186

SKRABALAK, D. S., LOONEY, A. L. 1993: Supernumerary teeth associated with facial swelling in a dog. J. Am. Vet. Med. Assoc. 203: 266

STELLZIG, A., BASDRA, E. K., KOMPOSCH G. 1997: Mesiodentes: incidence, morphology, etiology. J. Orofac. Orthop. 58: 144-153

THOLEN, M., HOYT, R. F. 1990: Oral Pathology. In: Bojrab, M. J, Tholen, M. Small Animal Oral Medicine and Surgery. Lea \& Febiger, Philadelphia, pp. 25-55

THONGUDOMPORN, U., FREER, T. J. 1998: Prevalence of dental anomalies in orthodontic patients. J. Aust. Dent. 43: 395-398

VERSTRAETE, F. J. M. 1999: Self-Assessment Colour Review of Veterinary Dentistry.Manson Publishing, London, pp. 10-217

WIGGS, R. B., LOBPRISE, H. B. 1997: Clinical Oral Pathology. In: Wiggs, R. B., Lobprise, H. B. Veterinary Dentistry Principles \& Practice. Lippincott - Raven, pp. 104-139 
Plate XI

Pavlica Z. et al.: Teeth... pp. 65-72

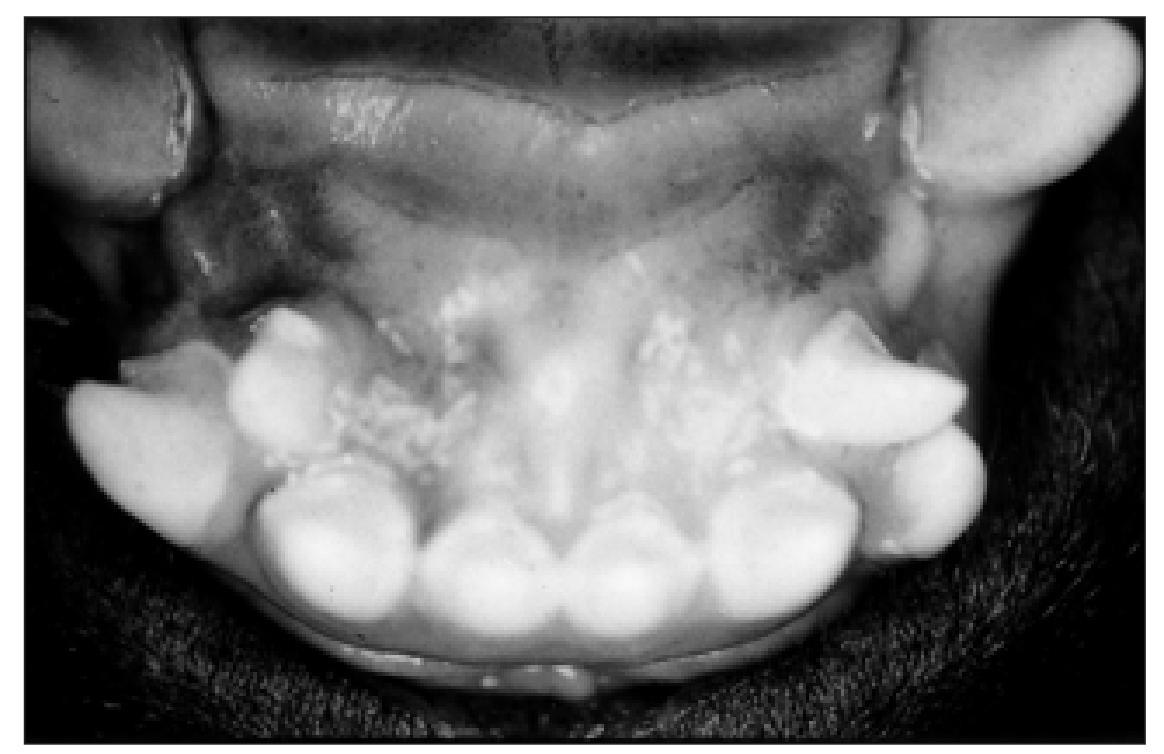

Fig. 1. Left and right supernumerary third upper incisors

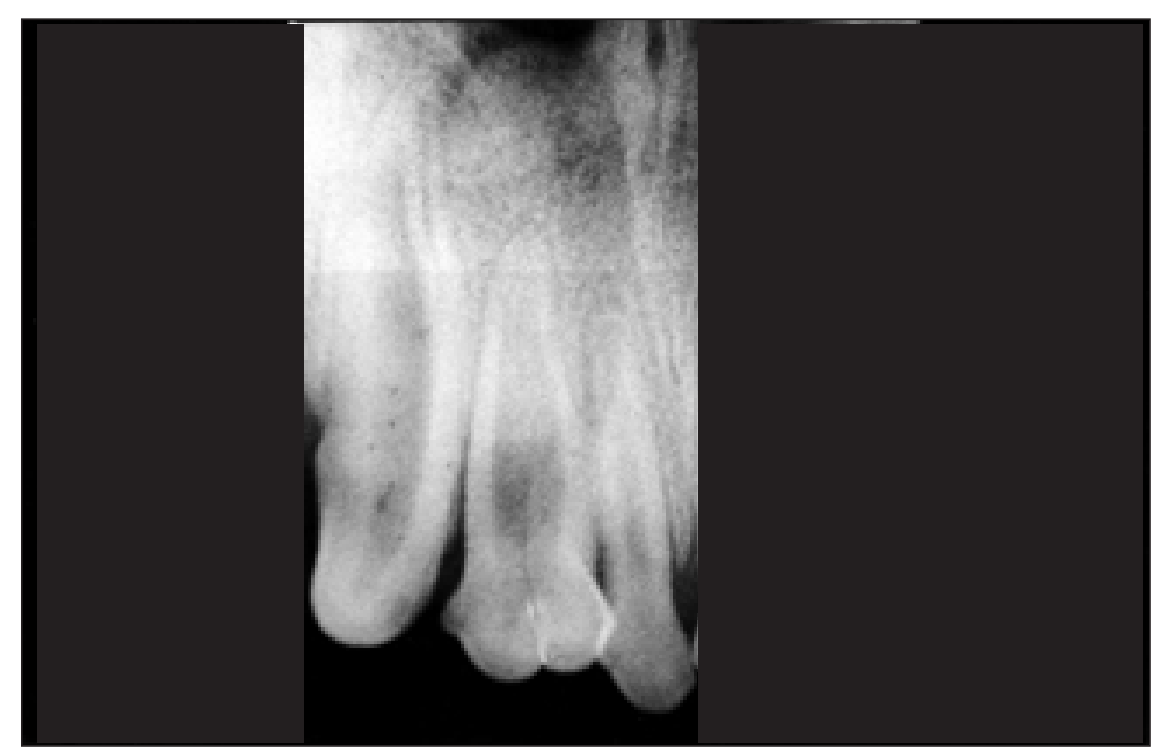

Fig. 2. Gemination of the second upper left incisor 


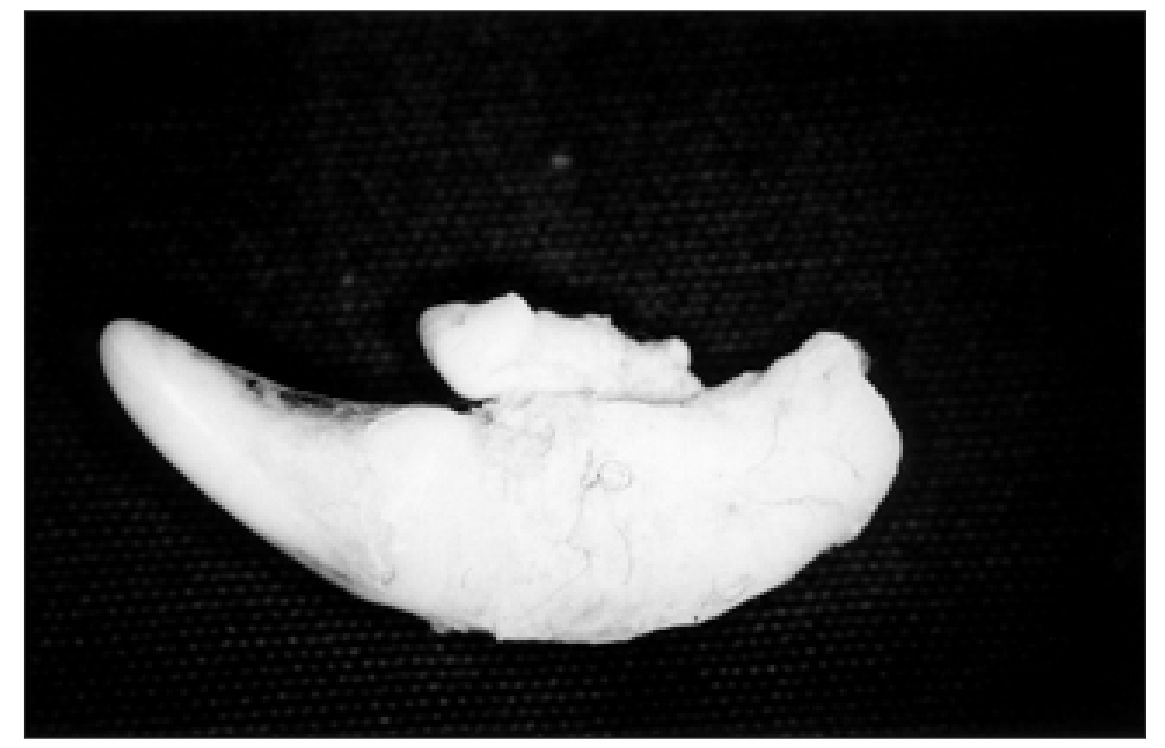

Fig. 3. Concrescence of the lower left canine and the first premolar in German Shepherd

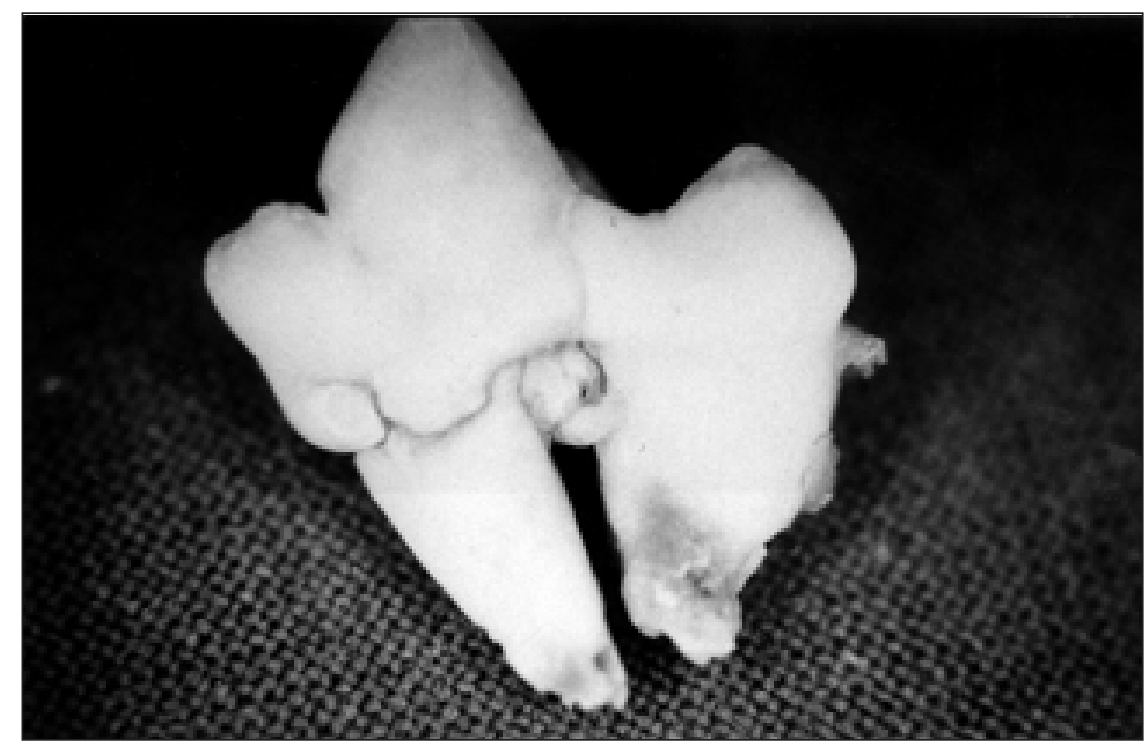

Fig. 4. Enamel pearls on the lower first molar 